\section{DE DE GRUYTER} OPEN
Research Article

(c) 2018 Olihe Adaeze Ononogbu and Chikodiri Nwangwu. This is an open access article licensed under the Creative Commons Attribution-NonCommercial-NoDerivs License (http://creativecommons.org/licenses/by-nc-nd/3.0/).

\title{
Counter-Insurgency Operations of the African Union and Mitigation of Humanitarian Crisis in Somalia
}

\author{
Olihe Adaeze Ononogbu, Ph.D
}

Department of Political Science, University of Nigeria, Nsukka

\section{Chikodiri Nwangwu}

Department of Political Science, University of Nigeria, Nsukka

Doi: $10.2478 / \mathrm{mjss}-2018-0032$

\begin{abstract}
The protracted armed conflict in Somalia has engendered an unprecedented humanitarian crisis; one that makes it a leading storehouse of the worst humanitarian conditions in the world. The intervention of the African Union (AU) through its third Peace Support Operation - the African Union Mission in Somalia (AMISOM) - was aimed at supporting the Transitional Federal Institutions in the stabilisation of the country, advancing dialogue and reconciliation as well as facilitating the provision of humanitarian support. The achievement of the humanitarian component of the mission's mandate is largely contingent on the first two mandates. Essentially, this study interrogated the interface between the implementation of the humanitarian component of AMISOM mandate and the control of the worsening conditions of Somali internally displaced persons and refugees. Anchoring analysis within the classical approach to national security, the study found that the restoration of relative stability in the polity has not widened access to economic and humanitarian assistance in the terror-laden state of Somalia. Thus, greater commitment of major stakeholders, especially the United Nations (UN), the United States as well as the $A U$ is required in the transmutation of AMISOM and Somalia National Armed Forces into a force that is entirely indigenous to the people of Somalia. This will serve as an elixir to the ever-constricting humanitarian corridor that has exacerbated the conditions of the victims of forced migration in Somalia.
\end{abstract}

Keywords: Somalia, al-Shabaab, sustainable counter-insurgency, humanitarian crisis, African Union, AMISOM mandate

\section{Introduction}

Since the founding of the Fund for Peace in 2005, it has continued to accord the Federal Republic of Somalia an unenviable position in the Fragile States Index (formerly called Failed States Index). This is largely because of the non-existence of an effective central government that could guarantee the integrity of the country for almost three decades now. The absence of an effective government since 1991 has culminated in violent armed struggle, dearth of public services, widespread corruption and proliferation of victims of forced or involuntary migration in the country. Invariably, the history of state failure in Somalia is traceable to the internecine armed conflict which became full-blown after the collapse of the dictatorial regime of Major General Siad Barre on 27 January 1991. After 26 years of unbroken civil war, the prospect of attaining political stability is still far-fetched. Fighting between the various clan-based factions and al-Shabaab insurgents on the one hand and the African Union Mission in Somalia (AMISOM)-supported Somalia National Armed 
Forces (SNAF) on the other hand has spanned several years. The unequalled humanitarian disaster arising from this conflict has worsened the conditions of Internally Displaced Persons (IDPs) in Somalia. The prevailing humanitarian situation is traceable to at least three interrelated 20th century phenomena: colonialism, Cold War and the dictatorial regime of General Barre.

The combination of these forces in the post-colonial Somalia heralded the clan-based crisis of the 1980s and the political turmoil that had crystallised since 1991. For instance, Andre \& Majid (2002), Egbo (2001), Francis (2006), Møller (2009), Dagne (2011), Margesson et al. (2012), Nwangwu (2014), Maxwell et al. (2014), Wondemagegnehu \& Kebede (2017), among others, have highlighted the dynamic interplay of the disparate (if not contradictory) Italian and British colonial policies in Somalia, General Barre's alliance with the Soviet Union during the heyday of Cold War as well as General Barre's dictatorial disposition, in the origin and exacerbation of the Somali conflict. The political romance between Somalia and the Soviet Union under the Cold War regime culminated in the implementation of some socialist ideals like scientific socialism. The doctrine of scientific socialism was an admixture of Marxism and Quranic interpretations. Similarly, in line with his ideology of Pan-Somalism, General Barre formed the Supreme Revolutionary Council (SRC) through which he proclaimed the end of tribalism, nepotism, corruption and misrule. Pan-Somalism advocated the unification of all ethnic Somalis under one flag and one nation. It was the basis upon which the Ethio-Somali War (otherwise called the Ogaden War) of July 1977 to March 1978 was prosecuted. Prior to the war, SRC aligned itself with the Soviet Union and denounced the USAfrican policies as imperialist. Through the existence of strong diplomatic intercourse between Somalia under General Barre and the defunct Soviet Union, the former attained phenomenal economic development until mid-1970s when the latter withdrew its support.

Despite the rhetoric about Pan-Somalism, General Barre consistently pursued clannish policies which totally negated the ideology. His defeat in the 1977-78 expansionist war by the Soviet Union- and Cuba-backed new Marxist government in Ethiopia generated severe humanitarian and refugee crises. Thus, Alexander as cited in Moller (2009:7) affirms that "by 1983, as many as 1.3 million refugees had arrived in Somalia causing severe strain on the economy particularly in the Isaaq-dominated northern area". Consequent upon the widespread political, economic and humanitarian crises that accompanied General Barre's dictatorial regime, several attempts were made to unseat him especially by the military officers from Majeerteen clan and the Isaaq-dominated Somali National Movement (SNM). Throughout the early 1980s, the SNM prosecuted a low intensity guerrilla war against the government. Similarly, in 1989 a group of Somali exiles from the Hawiye clan formed the United Somali Congress (USC) in Rome. The USC militia successfully drove General Barre out of Mogadishu on January 27, 1991 in spite of the repressive tendencies of his special force- the Red Berets.

Somalia degenerated into anarchy as rival ethnic warlords battled for supremacy and the control of state power. The conflagration spread across the country, sparking an ill-fated international humanitarian intervention. For almost 30 years now, Somalia has remained a lawless zone with no effective government. This situation is largely treated as the cause as well as effect of the escalating militancy and terrorism perpetrated by various Islamist, extremist and militant groups, especially al-Shabaab. According to the United Nations High Commissioner for Refugees (UNHCR) 2012 report, in the first half of 2011 alone, more than 83,000 Somalis fled into Kenya and over 54,000 into Ethiopia. In July, daily arrivals in each country ranged from 1,300 to 1,700. An additional 2,600 Somalis had crossed the north-western border into Djibouti by mid-2011. The situation has remained critical and deteriorating. Although famine conditions are no longer prevalent in the country, approximately two million Somalis are still considered food insecure (UNHCR, 2012). In corroboration, the Office for the Coordination of Humanitarian Affairs (OCHA) noted that the humanitarian situation continues to deteriorate and the possibility of famine in 2017 persists (OCHA, 2017). In addition, there are one million internally displaced persons in Somalia and another one million Somali refugees in neighbouring countries (Ging, 2013). Similar report from the former Chairperson of the African Union Commission - Nkosazana Clarice Dlamini-Zumaindicates that there are over one million Somali refugees in the region. These refugees are found predominantly in Djibouti, Egypt, Eritrea, Ethiopia, Kenya, Tanzania, Uganda and Yemen. The report also puts the number of IDPs at one million who are living in excruciating conditions in camps 
across the country (Dlamini-Zuma, 2013).

AMISOM is a regional peacekeeping mission established in early 2007 and mandated inter alia, to facilitate humanitarian operations, including the repatriation and reintegration of refugees and the resettlement of IDPs. The mission also supports the Somali forces in their counter-terror operations of al-Shabaab. Although the security situation has reasonably improved since the creation of the Federal Government of Somalia (the successor to the internationally recognised but domestically unpopular Transitional Federal Government) on August 20, 2012, there are a number of incidents which continue to restrict and undermine access to and delivery of humanitarian assistance to the needy population. For instance, humanitarian needs in South-Central Somalia have remained high as a result of worsening security situation engendered by road blockade since the area came under the control of the fragile Federal Government of Somalia. The near absence of public infrastructure, including health, education and other social services, accounts for the deteriorating conditions of the war-weary population, especially the vulnerable groups like women, children and persons living with disability. Consequently, this study investigates the role of the counter-insurgency operations of the $\mathrm{AU}$ in the mitigation of humanitarian crisis in Somalia.

\section{Methodology}

This study is a qualitative research. It relied basically on the documentary method for the generation of data. The documentary method is concerned with the analysis of documents that contain information about a given phenomenon under investigation. Simply put, a document is a written text. According to Payne and Payne (as cited in Mogalakwe, 2006: 221), "documentary method is the technique used to categorize, investigate, interpret and identify the limitations of physical sources, most commonly written documents whether in the private or public domain". The documentary research method is also often considered a monopoly of professional historians, librarians and information science specialists. Thus, it has had little attention in social and behavioural sciences compared to other methods such as statistics and quantification which are popular forms of data collection and analysis. The method, therefore, is largely under-utilised and often considered a subsidiary research method in the social sciences. However, it is not less rigorous and scientific because of its adherence to the tenets of scientific protocol.

Sources of documentary research include historical documents such as laws, declarations, statutes, and people's accounts of events and periods. They also include reports based on official statistics, as well as governmental records, mass media, literary texts, drawings and personal documents such as dairies and biographies. The methodological significance of this tool cannot be over-emphasised. It was useful in identifying information gaps that needed to be filled, formulating the research problem, developing a theoretical framework and articulating the research methodology. This data gathering technique enables access into the inner recesses of group life, organisational structure, bureaucratic processes as well as the motivations for individual behaviour. In relation to the study, data were gathered from official sources such as the African Union Peace and Security Council, African Union Commission, UN Office for the Coordination of Humanitarian Affairs, UN Security Council, UN High Commissioner on Refugees, and so on. The study also included data from journal publications and conference papers, among others.

The mass of data generated were analysed using the qualitative descriptive method of data analysis. This method moves farther into the domain of interpretation because effort is made to understand not only the manifest but also the latent content of data with a view to discovering patterns or regularities in them. Tables were used for further illumination of the issues in the discourse. The study also utilised the classical theory of national security through which deeper theoretical insights were elicited as shall be seen below. Consequently, the study was able to establish the interface between the counter-insurgency operations of AMISOM-SNAF and the humanitarian crisis in Somalia.

\section{Theorising the Involvement of AMISOM-SNAF in the Somali Conflict}

The establishment of AMISOM in January 2007 as the third Peace Support Operations (PSOs) of 
the African Union (AU) as well as the implementation of the Mission's mandate has generated a flurry of theoretical justifications. The principal school of thought on the role definition for AMISOM in the containment of the rampaging al-Shabaab militancy and the consequent amelioration of the humanitarian crisis in Somalia is contingent on the security-oriented approach. This approach favours the enhancement of security system and the continuing defeat of insurgents. Thus, the study and understanding of the interface between the implementation of the humanitarian component of AMISOM's mandate and the worsening conditions of IDPs and refugees of Somali extraction in the terror-ridden state of Somalia is guided by the security-oriented approach.

The security-oriented approach otherwise known as the classical theory of national security has remained the most dominant perspective within the extant literature. This orthodox conceptualisation of national security is associated with state-centrism and militarism. The central thrust of the perspective is that national defence, security and protection of a country from attack or subversion is the ultimate raison d'être of the state. Preparation for military action, intelligence gathering and espionage, among others, are included in national defence and security strategies of a country.

The state-centric scholarship which has dominated the international system evolved as a product of the Westphalia state system in 1648. Thus, it conceptualises national security purely as a politico-military phenomenon. It is used to refer to the capacity of a ruling group to use state power to protect its interest or values from external threats as well as maintain order internally (Nwangwu \& Ononogbu, 2014; Nwangwu et al., 2016). Everything the state or its agencies do is justified in the name of national security. This has been possible because much of the leadership in Africa and the rest of the world have rigidly adhered to the concept of national security devised during the seventeenth century in accordance with realities of the time. However, the unbridled use of instruments of coercion otherwise called 'hard security' which is associated with this perspective has been carpeted by Mbah (2008:156) when he argued that "the greater application of hard security is an indication that the ruling groups are in fact insecure, notwithstanding the appearance of strength represented by coercive instruments of the state".

Although security demands military power sufficient to dissuade or defeat an attack, there are so many non-military elements that are required to generate effective military power that a concern for security can never be restricted solely to the final military end product. Hence, there is general acceptance that national security must go beyond the narrow focus on external attack and the use of the military to defeat it (Nwangwu \& Ononogbu, 2014). Accordingly, Nnoli (2006:17) avers that:

although a concern for security must ultimately focus on the physical danger to a state that is posed by imbalances in military power, a concern for security cannot be limited simply to military power. A state fashions the military power it deploys from various elements: the economic wealth of the nation, the quality of its political leadership, the cohesiveness of the polity, the motivation of its citizenry, the nature of its military leadership, its access to food and raw materials, and so on.

This unrestrained use of coercion to preserve a state of affair usually favourable to the governing elite is implicated in the emergence and escalation of al-Shabaab terrorism and the attendant deteriorating humanitarian conditions of Somali IDPs and refugees. The implementation of AMISOM mandate has been strengthened over the years through a progressive increase in the force strength of the Mission. For instance, the force strength of AMISOM which were two battalions each provided and deployed by Uganda and Burundi in 2007 and 2008 respectively has been expanded to a maximum of 22,126 uniformed personnel, comprising 21,586 soldiers and 540 police officers. The progressive increase in the force strength has been made possible through United Nations Security Council (UNSC) Resolutions 1964 (2010), 2036 (2012) and 2124 (2013). While the progressive numerical expansion of AMISOM-SNAF strength and its attendant daring offensives have significantly contained al-Shabaab insurgency in major cities of Somalia, this has not translated into wider access to humanitarian assistance by IDPs and refugees of Somali extraction. This is paradoxical.

The resultant effect of this state of affair is the unprecedented and ever-constricting humanitarian corridor in Somalia which has exacerbated the conditions of the IDPs. Although increasing food insecurity in Somalia can be partly attributed to natural causes such as drought, the principal causative factor remains the escalation of armed conflict between the AMISOM-backed 
SNAF and al-Shabaab insurgents. The UNHCR reports that 73,000 people have been internally displaced since the military offensive launched in March 2014. This has negatively impacted on food production as farmers are forced away from their fields. Perhaps most significantly, alShabaab insurgents often imposed embargoes on shipments of humanitarian aid by road into much of the territory captured during its offensive (Nwangwu, 2014). This has further exacerbated food insecurity in Somalia.

\section{Deployment of AMISOM Force and the Counter-Insurgency Operations in Somalia}

The legal foundation stone for the justification of regional peacekeeping operations is situated under the ambit of Chapter VIII of the UN Charter. Acting specifically under Articles 52 and 53 of the Charter, the Declaration on the Enhancement of Cooperation between the UN and Regional Arrangement in the Maintenance of International Peace of 9 December 1994 as well as the Communique of the African Union Peace and Security Council (AU-PSC) of 19 January 2007, the UNSC on 20 February 2007 passed Resolution 1744 which reiterated its support for the Transitional Federal Institutions (TFIs). The Resolution also authorised the creation of AMISOM; thereby endorsing the previous AU decision to found a PSO in Somalia. It calls for a national reconciliation congress of major stakeholders, especially political, clan-based and religious leaders as well as members of civil society organisations. Thus, AMISOM was formed by the AU-PSC as a regional PSO with the mandate to address the protracted problems of militancy and terrorism, support the Transitional Federal Institutions (TFIs) in their effort of stabilising the country as well as widen access to the inflow of humanitarian assistance to the terror-ravaged country. The Mission's mandate is contained in paragraph (4) (a) to (e) of Resolution 1744 of the UNSC as well as the Communiqué of the AU-PSC 69th Meeting of 19 January 2007.

The poorly-implemented Inter-Governmental Authority on Development (IGAD) Peace Support Mission to Somalia (IGASOM) was outmoded and supplanted by AMISOM. IGASOM was a training mission approved by the AU-PSC as well as UNSC in September 2006. The AU-PSC, therefore, deployed AMISOM for an initial but renewable period of six months with the ultimate aim of contributing to the initial stabilisation phase in Somalia. The Mission was also intended to eventually crystallise into a UN mission that would support a long-term stabilisation and postconflict peace building in Somalia.

Initially, the UNSC authorised the AU-PSC to deploy 8,000 AMISOM troops in Somalia. The Mission's mandate was renewed by the UNSC on 22 December 2010 through Resolution 1964. Correspondingly, the Resolution increased the UN logistical support from 8,000 to 12,000 AMISOM troops. On 30 September 2011, UNSC through Resolution 2010 renewed AMISOM's mandate until 31 October 2012 and expanded the scope of logistics support provided by United Nations Support Office for AMISOM (UNSOA) to include catering, communications, cleaning, furniture and welfare. On 22 February 2012, the UNSC through Resolution 2036 expanded and extended AMISOM's footprint out of Mogadishu into four established sectors of Somalia. It also boosted AMISOM's force strength from 12,000 to a maximum of 17,731 uniformed personnel, comprised mainly of troops and personnel of Formed Police Units (FPU). On 21 November 2012, UNSC Resolution 2077 extended the mandate of AMISOM and UNSOA until 7 March 2013, in order to give the UN and the AU time to conduct strategic reviews. Furthermore, the UNSC through Resolution 2124 expanded the logistical support package for AMISOM by increasing its force strength from 17,731 to a maximum of 22,126 uniformed personnel, comprising 21,586 soldiers and 540 police officers, until 31 October 2014. However, the most recent decision of the UN on Somalia is contained in the UNSC Resolution 2355 of 26 May, 2017. Among others, the Council extends AMISOM's authorisation until 31 August 2017 with a maximum strength of 22,126 uniformed personnel. Table 1 shows some relevant resolutions of the UNSC on the situation in Somalia since 2007. 
Table 1: Relevant UNSC Resolutions on AMISOM and Somalia

\begin{tabular}{|c|c|c|c|}
\hline $\mathbf{S} / \mathbf{N}$ & $\begin{array}{l}\text { UNSC } \\
\text { Resolutions }\end{array}$ & $\begin{array}{l}\text { Date } \\
\text { Adopted }\end{array}$ & Content/Key Decisions \\
\hline 1 & \begin{tabular}{|l|} 
Resolution \\
1744
\end{tabular} & $\begin{array}{l}\text { February 20, } \\
2007\end{array}$ & $\begin{array}{l}\text { Authorising the establishment of AMISOM within six months, with the mandate of } \\
\text { protecting the Transitional Federal Government. }\end{array}$ \\
\hline 2 & \begin{tabular}{|l|} 
Resolution \\
1772
\end{tabular} & $\begin{array}{l}\text { August 20, } \\
2007\end{array}$ & $\begin{array}{l}\text { Renewal and extension of AMISOM's mandate by six months. It also resolved to take } \\
\text { action against parties threatening AMISOM, the Transitional Federal Government (TFG) } \\
\text { and the Somali peace process. }\end{array}$ \\
\hline 3 & \begin{tabular}{|l|} 
Resolution \\
1801
\end{tabular} & $\begin{array}{l}\text { February 29, } \\
2008\end{array}$ & $\begin{array}{l}\text { Renewal and extension of AMISOM's mandate by six months. It also authorised the } \\
\text { mission to take necessary measures in order to ensure the security of key } \\
\text { infrastructures. }\end{array}$ \\
\hline 4 & $\begin{array}{l}\text { Resolution } \\
1831\end{array}$ & $\begin{array}{l}\text { August 19, } \\
2008\end{array}$ & Renewal of AMISOM's mandate. \\
\hline 5 & \begin{tabular}{|l|} 
Resolution \\
1844
\end{tabular} & $\begin{array}{l}\text { November } \\
20,2008\end{array}$ & $\begin{array}{l}\text { Calling upon states to prevent individuals threatening Somalia's TFG and AMISOM from } \\
\text { entering into or transiting their territories. }\end{array}$ \\
\hline 6 & $\begin{array}{l}\text { Resolution } \\
1863\end{array}$ & July 9, 2009 & Renewal of AMISOM's mandate. \\
\hline 7 & \begin{tabular}{|l|} 
Resolution \\
1910
\end{tabular} & $\begin{array}{l}\text { January 28, } \\
2010\end{array}$ & Extension of AMISOM's mandate to 31 January 2011. \\
\hline 8 & \begin{tabular}{|l|} 
Resolution \\
1964
\end{tabular} & $\begin{array}{l}\text { December } \\
22,2010\end{array}$ & $\begin{array}{l}\text { Extension of AMISOM's deployment to } 30 \text { September } 2011 \text {. It also recommended that } \\
\text { the mission's strength be increased from } 8,000 \text { to } 12,000 \text { troops. }\end{array}$ \\
\hline 9 & $\begin{array}{l}\text { Resolution } \\
2002\end{array}$ & $\begin{array}{l}\text { July } 29 \\
2011\end{array}$ & $\begin{array}{l}\text { Imposition of tough sanctions against parties threatening the security of Somalia, } \\
\text { obstructing the inflow of humanitarian assistance, and those violating an arms embargo } \\
\text { and international law in the country. }\end{array}$ \\
\hline 10 & \begin{tabular}{|l|} 
Resolution \\
2010
\end{tabular} & $\begin{array}{l}\text { September } \\
30,2011\end{array}$ & Extension of the deployment of AMISOM troops until 31 October 2012. \\
\hline 11 & $\begin{array}{l}\text { Resolution } \\
2036\end{array}$ & $\begin{array}{l}\text { February 22, } \\
2012\end{array}$ & $\begin{array}{l}\text { Widening of AMISOM's operational scope to four sectors as set out in the Strategic } \\
\text { Concept of } 5 \text { January } 2012 \text {. It also boosted AMISOM's force strength from } 12,000 \text { to a } \\
\text { maximum of } 17,731 \text { uniformed personnel, comprised mainly of troops and personnel of } \\
\text { FPU. }\end{array}$ \\
\hline 12 & $\begin{array}{l}\text { Resolution } \\
2073\end{array}$ & $\begin{array}{l}\text { November 7, } \\
2012\end{array}$ & $\begin{array}{l}\text { Renewal of AMISOM for four months and expansion of the UN logistical support package } \\
\text { for the mission to include funding for an additional } 50 \text { civilian personnel. }\end{array}$ \\
\hline 13 & $\begin{array}{l}\text { Resolution } \\
2093\end{array}$ & $\begin{array}{l}\text { March 6, } \\
2013\end{array}$ & $\begin{array}{l}\text { Called on the Secretary-General to continue to provide a logistical support package for } \\
\text { AMISOM, for a maximum of } 17,731 \text { uniformed personnel until } 28 \text { February } 2014 \text { and to } \\
\text { ensure the accountability and transparency of expenditure of the UN funds as set out in } \\
\text { paragraph } 4 \text { of Resolution } 1910 \text {. }\end{array}$ \\
\hline 14 & $\begin{array}{l}\text { Resolution } \\
2102\end{array}$ & May 2, 2013 & Establishment of the UN Assistance Mission in Somalia (UNSOM) \\
\hline 15 & \begin{tabular}{|l|} 
Resolution \\
2124
\end{tabular} & $\begin{array}{l}\text { November } \\
12,2013 \\
\end{array}$ & $\begin{array}{l}\text { Extension of AMISOM's mandate and increase of its force strength from } 17,731 \text { to a } \\
\text { maximum of } 22,126 \text { uniformed personnel, until } 31 \text { October } 2014 \text {. }\end{array}$ \\
\hline 16 & $\begin{array}{l}\text { Resolution } \\
2158\end{array}$ & $\begin{array}{l}\text { May 29, } \\
2014\end{array}$ & Extension of UNSOM's mandate for a period of 12 months. \\
\hline 17 & $\begin{array}{l}\text { Resolution } \\
2182\end{array}$ & $\begin{array}{l}\text { October 24, } \\
2014\end{array}$ & $\begin{array}{l}\text { Extension of AMISOM's mandate until } 30 \text { October 2015. The Council reiterated that the } \\
\text { arms embargo on Somalia shall not apply to deliveries of weapons, ammunition or } \\
\text { military equipment or the provision of advice, assistance or training, intended solely for } \\
\text { the development of the Security Forces of the Federal Government of Somalia. }\end{array}$ \\
\hline 18 & \begin{tabular}{|l|} 
Resolution \\
2221
\end{tabular} & $\begin{array}{l}\text { May 26, } \\
2015\end{array}$ & Extension of UNSOM's mandate until 7 August 2015. \\
\hline 19 & \begin{tabular}{|l|} 
Resolution \\
2232
\end{tabular} & \begin{tabular}{|l|} 
July 28 \\
2015 \\
\end{tabular} & $\begin{array}{l}\text { The Council emphasised the importance of continuing offensive operations against al- } \\
\text { Shabaab. }\end{array}$ \\
\hline 20 & \begin{tabular}{|l|} 
Resolution \\
2245
\end{tabular} & $\begin{array}{l}\text { November 9, } \\
2015\end{array}$ & $\begin{array}{l}\text { UNSOA changes to UNSOS and is responsible for support to AMISOM, UNSOM and the } \\
\text { Somali National Army. }\end{array}$ \\
\hline 21 & $\begin{array}{l}\text { Resolution } \\
2289\end{array}$ & $\begin{array}{l}\text { May 27, } \\
2016\end{array}$ & $\begin{array}{l}\text { Authorising a short technical rollover of AMISOM until } 8 \text { July } 2016 \text {. This is aimed at } \\
\text { allowing Council members time to assess the results of their } 17-22 \text { May Somalia-focused } \\
\text { visiting mission to the Horn of Africa and the possible implications for the AMISOM } \\
\text { mandate. }\end{array}$ \\
\hline 22 & $\begin{array}{l}\text { Resolution } \\
2297\end{array}$ & July 7, 2016 & Extension of AMISOM's mandate until 31 May 2017. \\
\hline 23 & \begin{tabular}{|l|} 
Resolution \\
2346
\end{tabular} & $\begin{array}{l}\text { March 23, } \\
2017\end{array}$ & Extension of the mandate of the UNSOM until 16 June 2017. \\
\hline 24 & \begin{tabular}{|l} 
Resolution \\
2355
\end{tabular} & $\begin{array}{l}\text { May 26, } \\
2017\end{array}$ & $\begin{array}{l}\text { Extension of AMISOM's authorisation until } 31 \text { August } 2017 \text { with a maximum strength of } \\
22,126 \text { uniformed personnel. }\end{array}$ \\
\hline
\end{tabular}

Source: Compiled by the authors mainly from Security Council Report. Available from: http://www.securitycouncilreport.org/un-documents/somalia/. 
AMISOM has basically three components. These are Military, Police and Civilian who work hand in hand to achieve the Mission's mandate. AMISOM staff is drawn from a wide range of countries within Africa. The headquarters of the military component is staffed by officers from Burundi, Cameroon, Djibouti, Ethiopia, The Gambia, Ghana, Kenya, Niger, Nigeria, Senegal, Sierra Leone, Uganda and Zambia. However, many of its troops are drawn from six countries viz: Burundi, Djibouti, Ethiopia, Kenya, Sierra Leone and Uganda. As noted above, the strength of AMISOM uniformed personnel stands at 22,126. Along with the current force headquarters staff of 81 , the military component has 5,432 troops from Burundi, 1,000 from Djibouti, 3,664 from Kenya, 850 from Sierra Leone, 4,395 from Ethiopia and 6,223 from Uganda (www.amisom-au.org). On the other hand, the police component is made up of Professionals or Senior Leadership Team (SLT), FPU and Individual Police Officers (IPOs). The IPOs are drawn from Burundi, The Gambia, Ghana, Kenya, Nigeria, Sierra Leone, Uganda and Zimbabwe while the FPUs from Nigeria and Uganda each comprise of 140 officers. The IPOs are deployed in all the AMISOM sectors. It currently has 515 police officers and is comprised of 230 IPOs from Ghana, Nigeria, Sierra Leone and Uganda; 280 FPUs from Nigeria and Uganda, and 5 SLT officers from Burundi, The Gambia, Ghana, Nigeria and Uganda, (www.amisom-au.org). Lastly, the Mission's civilian component is limited to assisting the Federal Government of Somalia in re-establishing functioning state institutions and delivery of humanitarian services to the people of Somalia. Originally based in Nairobi, the component was relocated to Mogadishu in May 2011. The civilian component is made up of six units which includes Political, Humanitarian, Gender, Civil Affairs, Security and Safety, Public Information and Administration Units.

By and large, the AMISOM military component has been instrumental in helping SNAF push al-Shabaab out of much of southern Somalia, including major towns and cities. It has created a relatively secure environment which has ensured the commencement of the Somali peace process, allowed local population the opportunity to re-create accountable governance institutions that are poised to deliver essential services, rebuild the local economy and create linkages to the national economy and government.

Table 2: Showing AMISOM Troop \& Police Contributing Countries

\begin{tabular}{|c|l|c|c|c|c|}
\hline S/N & Country & \multicolumn{2}{|c|}{ Armed Personnel } & \multicolumn{2}{|c|}{ Casualties } \\
\hline & & Troops & Police & Killed & Missing/captured \\
\hline 1 & Uganda People's Defence Force & 6,223 & 201 & 83 & \\
\hline 2 & Burundi National Defence Force & 5,432 & & 417 & 4 missing; 1 captured \\
\hline 3 & Ethiopian National Defence Force & 4,395 & & 2 & \\
\hline 4 & Kenya Defence Forces & 3,664 & 48 & 154 & \\
\hline 5 & Djibouti Armed Forces & 1,000 & & 8 & \\
\hline 6 & Republic of Sierra Leone Armed Forces & 850 & 47 & & \\
\hline 7 & Nigeria Police Force & & 200 & & \\
\hline 8 & Ghana Police Service & & 56 & & \\
\hline & Total & $\mathbf{2 1 , 5 6 4}$ & $\mathbf{5 5 2}$ & $\mathbf{6 6 4}$ & $\mathbf{5}$ \\
\hline
\end{tabular}

Source: Nwangwu, C. (2014). "The Counter-Terrorism Operations of AMISOM-SNAF and Control of Humanitarian Crisis in Somalia", Journal of International Relations and Diplomacy (JIRAD) 1 (1\&2), 222-241.

Prior to the passage of the UNSC Resolutions 2036 and 2124 of 2012 and 2013 respectively, which among other things, expanded the logistical support package for AMISOM by increasing its force strength from 12,000 to 17,731 and from 17,731 to a maximum of 22,126 uniformed personnel, AMISOM comprised merely two battalions of 1,600 troops each from Uganda and Burundi. Nigeria and Ghana which had earlier pledged 850 and 350 troops respectively could not deploy because of paucity of logistical and financial resources. In the same vein, expected troop deployment by Sierra Leone was delayed as a result of logistical supply problems involving the acquisition of ammunition. Thus, sourcing and deploying its personnel undermined the implementation of the Mission's 
mandate. Some of the TCCs which pledged to deploy troops lacked the logistical, institutional and financial capabilities to do so. Furthermore, AMISOM still lacks the numbers to control its different areas of operations. According to Seguí (2013:9), "a force of 35,000 is required to fully undertake the responsibilities of this multidimensional peace support mission". However, the AU has been unable to convince Member States to deploy such numbers of troops for a variety of reasons that include limited available forces and budgets as well as other emerging threats or internal armed conflicts within the territories of the TCCs that need to be addressed. For instance, the Boko Haram insurgency which started as a domestic terrorist organisation in Nigeria later expanded and became a regional contagion, especially within the Lake Chad Basin. This has affected the Nigerian government and other members of the Multinational Joint Task Force from fulfilling their troop contributions and budgetary obligations to the AMISOM. Needless to say, it has heightened the likelihood of a possible reduction of funds allocated to the Mission. For instance, France has already announced its interest in reallocating financial resources from AMISOM to a probable AUled military intervention in Mali. More fundamentally, the core troop contributing countriesBurundi, Djibouti, Ethiopia, Kenya and Uganda - have publicly floated the idea of bringing their forces home (Maruf, 2017).

Other challenges bedevilling the Mission include complaints by AMISOM soldiers concerning their salaries and working conditions. According to Nwangwu (2014), the AU, in accordance with agreements signed with the TCCs, reimburses every AMISOM soldiers at a rate of US\$600 per month; a pittance when compared to the hazardous working conditions they are exposed to. AMISOM has also faced a number of challenges related to the coordination of troops. The intricacy of the integration of different national troops, which entails the harmonisation of a variety of different institutional cultures, capacities and methods, has been complicated and time-consuming. Tensions related to strategies and priorities among different troop contingents are quite common and remain unresolved. For instance, the Burundi-AMISOM contingent was resentful that the Kenyans were second in command of the mission when Burundians had participated longer and made more sacrifices. Similarly, the training of troops, particularly after the expansion of AMISOM operations, is still a significant challenge. More fundamentally, the AMISOM troops are still being perceived by the local population largely as 'occupying' troops.

Despite these challenges, the progressive increase of AMISOM force strength, among other strategies, has reasonably led to the restoration of peace and stability in Somalia. Al-Shabaab has been effectively evicted from major urban centres in southern Somalia, including Mogadishu, Baidoa, the port cities of Marka and Kismayo, as well as many other towns like Afgooye, Afmadow, Bay, Bakool and Hiran (Seguí, 2013). Consequently, Somalia is now facing a post-transitional phase characterised by the launching of a new constitution, inauguration of a new Federal Parliament and the swearing-in of Hassan Sheikh Mohamud as President of Somalia in August 2012. The government has been further consolidated following the successful presidential election of 8 February 2017 which led to the emergence of the former Prime Minister, Mohamed Abdullahi Mohamed, as the President. Nonetheless, these landmark achievements in the counter-terror campaign of the Mission have not been translated into a favourable environment for the delivery of humanitarian assistance to the needy population in Mogadishu and its environs. Instead, the counter-insurgency operations have remained central to the exacerbation of the humanitarian condition in Somalia as shall be demonstrated below.

\section{Counter-Terror Campaign of AMISOM and Delivery of Humanitarian Assistance}

A humanitarian crisis refers to an event or series of events which constitutes a critical threat to the health, safety, security or wellbeing of a community or other large group of people, usually over a wide area. It is caused by either natural or man-made disasters. Examples of natural disasters commonly associated with humanitarian crisis are drought, desert encroachment, flooding, storms, earthquakes, wild fire and volcanic eruptions. On the other hand, common anthropogenic factors that precipitate humanitarian crisis are armed conflicts, train crashes, air crashes, fires and industrial accidents. The humanitarian crisis in Somalia has been sustained through the combination of armed conflict and drought. The humanitarian mandate of AMISOM is contained in 
paragraph (4) (d) of the UNSC Resolution 1744 of 2007. The provision states that AMISOM shall contribute, as may be requested and within capabilities, to the creation of necessary security conditions for the provision of humanitarian assistance. The mandate further provides that AMISOM shall facilitate, as may be required and within capabilities, humanitarian operations, including the repatriation and reintegration of refugees and the resettlement of IDPs. This is an implicit acknowledgement of the fact that the Mission lacks both the requisite material and human capacity to carry out full humanitarian mandate.

In the implementation of its narrow humanitarian mandate, AMISOM has continued to facilitate the delivery of humanitarian assistance in Somalia. Since its deployment in 2007, the Mission has effectively secured all the necessary humanitarian corridors especially airport, seaport and major streets of Mogadishu. The Mission also provides essential escorts to humanitarian convoys headed for distribution points in and around Mogadishu. It continues to coordinate its activities and to cooperate with UN humanitarian organisations and other bodies working in Somalia to ensure greater access to humanitarian aid. This has enabled humanitarian workers to address the needs of the Somali population in the areas under the control of the Somali government. In terms of cooperation with humanitarian agencies, the AMISOM Humanitarian Liaison Unit works closely with OCHA-Somalia, UNICEF-Somalia, UNHCR-Somalia, World Food Programme and other UN bodies and non-governmental entities in order to establish effective coordination mechanisms and information sharing. The Mission also works in partnership with the Somali Ministry of Humanitarian Affairs and Resettlement, Ministry of Health, among other relevant authorities. Thus, the Mission has facilitated the voluntary return and resettlement of some refugees and IDPs.

Moreover, the Mission has continued, unswervingly, to provide life-saving support to the needy population, particularly in places where aid workers are non-existent or have limited access. This support includes potable water, healthcare and other basic amenities. Although the health facilities were designed to provide medical services for the deployed troops, AMISOM field hospitals and medical officials have been providing services to the civilian population. In view of the magnitude of the problems in Somalia, AMISOM medical facilities have become the foremost medical centre for the civilian population in Mogadishu and its environs. The field hospitals treat an average of 12,000 patients per month. Treatments vary from chronic medical diseases to surgical cases, both acute and chronic. Over $90 \%$ of these patients are from the local population, including officials and troops of the TFG (now Federal Government of Somalia), most of them requiring emergency surgical interventions (Kromah, 2010). During the flooding of 2012 in Jowhar, AMISOM donated medicines to the Governor of Middle Shabelle for distribution to victims of the disaster. Also within the period, the Mission worked hand in hand with the Mayor of Mogadishu to reconstruct four water wells in Dharkenley, Hamar Jabjab, Hamar Weyne, Wadajir Districts of Mogadishu (Dlamini-Zuma, 2013).

Nonetheless, AMISOM has been accused of not abiding by international humanitarian laws. Most of its military operations have led to civilian deaths through its heavy-handed response to alShabaab attacks. Initially, the AMISOM operational mandate did not include specific human rights components, in line with international standards for peacekeeping. According to Seguí (2013:7), "the international community prioritized strengthening the fledgling TFG and reducing al-Shabaab capacities and control, leading to a situation where the protection of the Somali civilian population was neglected". For instance, four months after AMISOM's deployment, one-third of Mogadishu's population abandoned the city because of the brutal violence and destruction caused by confrontations between the Mission and al-Shabaab forces. Thus, al-Shabaab offensives and the counter-insurgency operations of AMISOM-SNAF have severely exacerbated the humanitarian situation in Somalia. Large-scale displacement due to conflict has in the past created complex emergencies characterised by increased humanitarian needs. As a result of the ever-surging size of refugees and IDPs in the country, the Mission is widely regarded as an 'occupying' force instead of a peacekeeping one. This perception has denied the Mission the much-needed domestic cooperation and support. Thus, it should be squarely addressed if the Mission is to be viewed as legitimate and credible by the Somali population.

The military campaign by the AMISOM-SNAF to recover al-Shabaab controlled areas in southern and central Somalia continues to bloat the size of IDPs in Bakool and Lower Shabelle 
regions. The UNHCR report as cited in the October 2014 OCHA Somalia Humanitarian Bulletin shows that more than 7,000 people fled their homes in August and September due to the campaign. The Bulletin further notes that over 80,000 people have been uprooted from their homes since the initial launch of the military operation in March 2014 , with more than 73,000 during the first phase. The humanitarian condition has been further exacerbated by the threat posed by drought in the country. Overall, May 2017 OCHA Somalia Humanitarian Bulletin reports that the number of people in need of humanitarian assistance has increased from 6.2 million to 6.7 million people, while approximately $2,510,000$ people will be in crisis and 700,000 in emergency levels of food insecurity in June 2017. The prolonged drought has also led to lack of water and the largest outbreak of cholera in Somalia within the last five years with nearly 42,721 cases and almost 715 deaths as of 27 May 2017. By the same token, the report from the former Chairperson of the African Union Commission indicates that over 1 million Somali refugees are hosted mainly in Djibouti, Egypt, Eritrea, Ethiopia, Kenya, Tanzania, Uganda and Yemen (Dlamini-Zuma, 2013).

It is also important to note that contrary to the prevailing trite argument that effective prosecution of the AMISOM-SNAF counter-terror operations would lead to an opportunity for aid organisations to have greater access to people in need of humanitarian assistance, the successes recorded by the combined campaign of AMISOM-SNAF against al-Shabaab are yet to be translated into predictable humanitarian access. In other words, the relative stabilisation of national security since 2011, the retreat of al-Shabaab insurgents from Mogadishu and its environs, and the emergence of new permanent and democracy-oriented government institutions have not squarely addressed the fragile food security and humanitarian situation in the country.

Although the security situation has undoubtedly improved, several security incidents continue to restrict access to humanitarian services and even undermine the delivery of relief materials to the needy population. For instance, humanitarian needs in South-Central Somalia- a priority for UNHCR operations - have remained high as a result of worsening security situation and road blockade since the area came under the control of the fragile Federal Government of Somalia. Road access is highly inhibited in 28 districts in Southern and Central Somalia because of insecurity along major supply routes, road blockages and encirclement of newly recovered areas by armed non-state actors. Illegal check-points, banditry and demands for bribes are experienced even in areas where there has been no active conflict. In the first nine months of 2014, 2,200 conflict incidents with humanitarian implications were registered, of which 107 incidents were related to checkpoints (OCHA, 2014).

Furthermore, AMISOM-SNAF military campaign against al-Shabaab in key food producing areas of Somalia, such as Lower and Middle Shabelle and Lower and Middle Juba, has aggravated the humanitarian situation. Fighting usually disrupts the planting season, increases livestock movement and reduces access to markets and basic services. It also results in civilian casualties and displacement of people from their home areas and lead to increased violations against civilians. Furthermore, population movements could also increase the risks of transmission of diseases, including polio which re-emerged in Somalia in 2013.

The near absence of public infrastructure like health, education and other amenities, accounts for the deteriorating conditions of the war-weary population, especially the vulnerable groups like women, children and the physically challenged. Farmers have been unable to cultivate their land, thereby relying on food aid as the commercial gateways to Mogadishu and Belet Weyne are cut off. The costs of basic food products have skyrocketed with an average of $50 \%$ due to the blockage of the main roads. Water supply is also scarce and the price of 20 litres had tripled, from 1,000 to 3,000 (\$1.2 to $\$ 3.6$ ) Somali Shillings with people resorting to drinking unsafe river water as a result (OCHA, 2014).

Somalia's humanitarian crisis has, therefore, remained one of the largest and most complex in the world. Thus, the Somalia Humanitarian Country Team (2014:1) reports that:

an estimated 2.9 million people are in need of immediate life-saving and livelihood support. With roughly 30 percent of the total population in need, humanitarian needs in Somalia are significant. One in seven children under the age of five, or 203,000 children, is estimated to be acutely malnourished. More than 50,000 of these malnourished children are currently at death's doorstep, and without assistance this number could double in the next six months. Poor and 
inadequate basic social services continue to undermine the resilience of the people while 635,000 people in settlements need support to meet basic minimum standards including education, health, shelter and WASH. The child and maternal mortality rates for Somalia are among the highest in the world; one in every 10 Somali children dies before seeing their first birthday, while one in every 12 women dies due to pregnancy-related causes. Millions of Somalis remain vulnerable to disease outbreaks due to the absence or the weak state of health and WASH services. In some areas one in three children suffers from diarrhoea, while polio re-emerged in May 2013. There is no protective environment for vulnerable people particularly women and children.

In spite of the roles of both traditional humanitarian organisations and other stakeholders, the existing humanitarian response remains inadequate due to restriction of access and funding-related challenges. Considering the outcome of the 2011 and 2012 offensives, intensified military activities resulted to increased displacement of people from rural areas towards the urban centres in Baidoa, Mogadishu and Kismayo where access to basic services had been hitherto overstretched. Similarly, high number of child recruitment, abandonment of previously recruited children, separated and unaccompanied children and very high increase in sexual violence are usually associated with such situation. Children's access to education is disrupted due to military operation and resulting displacement and insecurity. The deprivation of children's right to education potentially has grave effects the longer the offensive lasts. The impact on children also includes physical harm and psycho-social trauma.

As if the foregoing humanitarian challenges occasioned by the campaign of AMISOM-SNAF against al-Shabaab insurgency are not enough, donor funding has also been limited. According to John Ging, the Director of the Coordination and Response Division of OCHA, as at 20 May 2014, the Consolidated Appeal for Somalia which requested US\$933 million for 2014 , has only been $19 \%$ funded at US $\$ 177$ million (UN News Centre, 2014). This limited donor funding has combined with AMISOM-SNAF counter-terrorism operations to dim the humanitarian survival of Somali refugees and IDPs. The largest components of the humanitarian appeal are food security and nutrition, which comprise more than half of the consolidated budget. Other areas of humanitarian assistance that have been affected by a lack of contributions include health, water/sanitation/hygiene, protection, shelter and education. For example, Ging further reports that on 27 May 2014, the UNICEF which provides more than $70 \%$ of healthcare needs stated that without new funds it would be forced to suspend provision of essential health services to women and children within a month. In a corroborative report, the May 2017 OCHA Somalia Humanitarian Bulletin shows that more than US $\$ 60$ million is immediately required to fund emergency needs that have been identified for a three-month operational response plan.

\section{Conclusion}

Essentially, this study investigated the interface between the counter-terrorism operations of AMISOM-SNAF and the control of humanitarian crisis in Somalia. It found that the counterinsurgency of the African Union against al-Shabaab offensives has unduly narrowed access to humanitarian assistance in Somalia. In contradistinction to the prevailing threadbare argument that effective prosecution of the AMISOM-SNAF counter-terror campaign would herald the prospect of humanitarian organisations to have greater access to people in need of humanitarian assistance, this paper argued that the successes recorded by the counter-insurgency operation are yet to be translated into predictable humanitarian access. Although the post-transitional phase of Somalia has witnessed some degree of political stability in terms of launching a new constitution, inaugurating a new Federal Parliament, swearing-in of Mr. Hassan Sheikh Mohamud as President of the Federal Republic of Somalia as well as the successful presidential election of 8 February 2017, these achievements have not been translated into a favourable environment for the delivery of humanitarian assistance to the needy population in Mogadishu and its environs.

Arising from the above, the study recommends that the UNSC, UNSOA and AMISOM should expedite action in the transmutation of AMISOM-SNAF into a force that is indigenous to the people of Somalia. The Federal Government of Somalia should place greater import on the creation of an inclusive, transparent and Somali-owned political system and security architecture that would bring 
about national integration and cohesion. Ultimately, only the people of Somalia can, in a sustainable manner, provide for the security that their people have been yearning for over the past decades. Thus, it is only under Somali-owned security architecture that the ever-constricting humanitarian access would be widened for greater humanitarian intervention.

\section{References}

African Union Peace and Security Council (2007). Report of the Chairperson of the Commission on the Situation in Somalia during the 69th Meeting, 19 January 2007 Addis Ababa, Ethiopia. Available from: http://www.peaceau.org/uploads/reporten-69th.pdf [accessed: 30 October 2016].

Andre, L.S. \& Majid, N. (2002). "The Livelihoods Gap: Responding to the Economic Dynamics of Vulnerability in Somalia", Disasters 26 (1), 10-27.

Dagne, T. (2011). "Somalia: Current Conditions and Prospects for a Lasting Peace", Available from: http://fas.org/sgp/crs/row/RL33911.pdf [accessed: 11 November 2016].

Dlamini-Zuma, N.C. (2013). Report of the Chairperson of the African Union Commission on the Situation in Somalia during Peace and Security Council 379th Meeting. Available from: http://cpauc. au.int/en/sites/default/files/psc-report-somalia-13-06-20130.pdf [accessed: 30 October 2015].

Egbo, S. (2001). Political Soldiering: Africa's Men on Horse Back. Enugu: John Jacob's Classic Publishers Ltd.

Francis, D.J. (2006). Uniting Africa: Building Regional Peace and Security Systems. Freetown: Ashgate Publishers.

Kromah, L. (2010). "The Role of AMISOM's Civilian Component", in V. Gounden (ed.), Conflict Trends: Civilian Dimension of Peacekeeping, 21-27. A publication of the African Centre for the Constructive Resolution of Disputes.

Margesson, R.; Dagne, T.; Hanrahan, C.E.; Ploch, L.; Rennack, D.E.; Brown, M.A. \& Chesser, S.G. (2012). Horn of Africa Region: The Humanitarian Crisis and International Response. A publication of Congressional Research Service.

Maruf, H. (2017). "AMISOM Marks 10 Years in Somalia, to Everyone's Regret", Voice of America, 6 March. Retrieved from: www.voanews.com/amp/3751556.html.

Maxwell, D.; Majid, N.; Stobaugh, H.; Kim, J.J.; Lauer, J. \& Paul, E. (2014). Lessons Learned from the Somalia Famine and the Greater Horn of Africa Crisis 2011-2012. Somerville: Feinstein International Center.

Mbah, P. (2008). "Elections and Human Rights in Nigeria", in O. Anichebe (ed.), Logic, Philosophy \& Human Existence, pp. 146-170. Nsukka: Afro-Orbis Publishing Co. Ltd.

Mogalakwe, M. (2006). "The Use of Documentary Research Methods in Social Research", African Sociological Review, 10 (1), 221-30.

Møller, B. (2009). The Somali Conflict: The Role of External Actors. Copenhagen: Danish Institute for International Studies.

Nnoli, O. (2006). National Security in Africa: A Radical New Perspective. Enugu: PACREP.

Nwangwu, C. (2014). "The Counter-Terrorism Operations of AMISOM-SNAF and Control of Humanitarian Crisis in Somalia", Journal of International Relations and Diplomacy (JIRAD), 1 (1\&2), 222-241.

Nwangwu, C. \& Ononogbu, A.O. (2014). "National Security and Sustainable Economic Development in Nigeria since 1999: Implication for the Vision 20:2020", Journal of Educational and Social Research, 4 (5), 129142.

Nwangwu, C., Ononogbu, O.A. \& Okoye, K. (2016). "Politicisation of the Counter-Insurgence Operations in Nigeria: Implication for the Political Economy", Global Journal of Arts Humanities and Social Sciences, 4 (2), 42-63.

Office for the Coordination of Humanitarian Affairs (2014). "Humanitarian Bulletin Somalia October 2014". Available

from: http://reliefweb.int/sites/reliefweb.int/files/resources/OCHA\%20Somalia\%20Humanitarian\%20Bulletin\%20 September\%202014.pdf [accessed: 5 November 2016].

Office for the Coordination of Humanitarian Affairs (2017). "Humanitarian Situation continues to deteriorate", May 2017 Humanitarian Bulletin, Issued 2 June, 2017.

Seguí, N.R. (2013). "Appraising the Role of the African Union in Somalia", Peace and Security Council Report, Issue 42.

Somalia Humanitarian Country Team (2014). "Humanitarian implications of SNAF/AMISOM Military Operation in Somalia". Available from: https://docs.unocha.org/sites/dms/Somalia/20140319_Humanitarian \%2520 Implications_Guiding\%25 [accessed: 30 October 2016].

United Nations High Commissioner on Refugees (2012). "Country Operations Profile- Somalia: Overview". Available from: $h$ ttp://www.unhcr.org/pages/49e483ad6.html [accessed: 30 October 2016].

United Nations High Commissioner on Refugees (2014). "UNHCR Country Operations Profile - Somalia". Available from: http://www.unhcr.org/pages/49e483ad6.html [accessed: 30 October 2016]. 
UN News Centre (2013). "Interview with John Ging, Director of Operations, UN Office for the Coordination of Humanitarian Affairs", Available from: http://www.un.org/apps/news/newsmakers.asp?News/D=78 \#sthash.HYNg2SeR.dpuf [accessed: 30 October 2016].

UN News Centre (2014). "Funding Critical for 'Fragile' Humanitarian Situation in Somalia, stresses UN Official". Available from: http://www.un.org/apps/news/story.asp?NewsID=47168\#.VHNTSJYjrIU [accessed: 30 October 2016].

United Nations Security Council (2007). Resolution 1744 Adopted by the Security Council at its 5633rd meeting, on 20 February 2007.

Wondemagegnehu, D.Y. \& Kebede, D.G. (2017). "AMISOM: Charting a New Course for African Union Peace Missions", African Security Review, 26 (2), 199-219. 